\title{
Childhood Lymphoma by AJCC v8 Stage
}

National Cancer Institute

\section{Source}

National Cancer Institute. Childhood Lymphoma by AJCC v8 Stage. NCI Thesaurus. Code C141202.

Staging systems for Hodgkin and non-Hodgkin lymphomas of childhood. Different systems are used for Hodgkin lymphoma and non-Hodgkin lymphoma of childhood. Staging of childhood Hodgkin lymphoma is the same as for the adult counterpart and is based on the Lugano classification criteria. The Ann Arbor staging system has been found to be inappropriate for staging of the non-Hodgkin lymphomas of childhood. The St. Jude staging system has been widely accepted and remains the recommended staging system for non-Hodgkin lymphomas of childhood. (from AJCC 8th Ed.) 